\title{
Evaluation of the chemical composition of Persea americana (Mill) pulp and seed
}

\author{
Nwaokobia K. ${ }^{*}$, Oguntokun M. O. ${ }^{2}$, Okolie P. L. ${ }^{3}$, Ogboru R. O. ${ }^{4}$ and Idugboe O. D. ${ }^{5}$ \\ ${ }^{1}$ Department of Agricultural and Bio-Environmental Engineering Technology, Federal Polytechnic, P.M.B 13, Auchi. Edo \\ State Nigeria. \\ ${ }^{2}$ Nutrition Laboratory, Department of Animal Production and Health, Federal University of Technology, P.M.B 704, \\ Akure, Ondo state, Nigeria. \\ ${ }^{3}$ Department of Chemistry, Delta State University, Abraka, P.M.B, 1, Abraka. \\ ${ }^{4}$ Research Coordinating Unit, Forestry Research Institute of Nigeria, P.M.B. 5054, Jericho Hills, Ibadan, Oyo state, \\ Nigeria. \\ ${ }^{5}$ Forestry Research Institute of Nigeria, Moist Forest Research Station, P.M.B 2444, Benin-city, Edo State, Nigeria. \\ ${ }^{*}$ Corresponding author. Email: nwaokobia.kingsley@gmail.com. Tel: +234-8066755184.
}

Copyright (@) 2018 Eke et al. This article remains permanently open access under the terms of the Creative Commons Attribution License 4.0, which permits unrestricted use, distribution, and reproduction in any medium, provided the original work is properly cited.

Received 15th May, 2018; Accepted 20th June, 2018

\begin{abstract}
The chemical composition of Persea americana pulp and seed was investigated. Edible and non-edible parts of the fruits (pulp and seeds) were compared considering their possible role in improving the sustainability of the food and pharmaceutical industries. The results obtained showed that the investigated samples contain minerals such as carbon $(17.29 \pm 0.03)$, hydrogen $(0.65 \pm 0.07)$, nitrogen $(4.13 \pm 0.01)$, oxygen $(76.88 \pm 0.09)$, sodium $(51.47 \pm 0.02)$, potassium (28.02 \pm 0.01$)$, calcium $(27.13 \pm 0.02)$, magnesium $(40.77 \pm 0.01)$, Iron $(12.01 \pm 0.01)$, zinc $(7.23 \pm 0.01)$, phosphorus $(31.63 \pm 0.04)$ and sulphur $(0.04 \pm 0.01)$ was found in the pulp while silicon, aluminum and chlorine was not detected. Proximate composition revealed that the seed of $P$. americana contains more of volatile matter and fixed carbon of $27.55 \pm 0.01$ and $58.35 \pm 0.04$ respectively; while the pulp has more moisture content of $81.69 \pm 0.01$ and ash of $1.02 \pm 0.01$. Ultimate analysis showed that the seed has more carbon and oxygen while the pulp has more nitrogen and hydrogen. Mineral contents of the investigated samples higher in seed than in pulp in terms of concentration. These various chemical compositions of the evaluated samples may be behind their importance in the therapeutical, cosmetic and pharmaceutical industry.
\end{abstract}

Keywords: Minerals, Persea americana, proximate composition, pharmaceutical, ultimate analysis.

\section{INTRODUCTION}

The fruit of Persea americana, commonly known as avocado, is an edible fruit from Central America which is easily adaptable in tropical regions including Nigeria. The species belong to the Lauraceae family. $P$. americana is one of the over 150 varieties of pear and avocado (Ejiofor et al., 2018). It is now being cultivated in the subtropical and tropical areas such as East and West Africa respectively. Its fruits which have a yellow-green to purple skin are described as a berry with a thick, fleshy mesocarp surrounding a single large seed. It weighs 50 grams to 1 kilogram with the mesocarp (edible flesh) contributing 50$80 \%$ and the seed 10 to $25 \%$ of its total weight (Nwaokobia et al., 2018).
It is one of the most productive plants per unit of cultivated area since it is a tropical fruit. $P$. americana stands out for its high nutritional value and it is beneficial to growth and development. It has also been the subject of intense and varied use during the past not only for food but also for medicinal purposes. American Indians have used the seeds to treat dysentery and diarrhea. It contains vitamins $A, B, C, E$ and other nutrients like magnesium, potassium, iron, niacin and folacin. Vitamin $A, C$ and $E$ help in protecting the body against eye cataract, cancer due to cell mutation as a result of its anti-oxidant activities, heart disease due to cholesterol (Rizvi et al., 2014) and in slowing down the aging process. Its high fibre content 
helps in lowering the effect of hypertension, obesity and cardiovascular disease (Rizvi et al., 2014). It also contains monounsaturated fats ( $70 \%$ of its fat) which makes it highly recommended for infants as it is beneficial for their development (Arukwe et al., 2012).

Presently, the seed of avocado has been under-utilized resource and termed as a waste in avocado processing and discarded in many countries, although, it is consumed in Niger Republic (Owolabi et al., 2005; Ojewole et al, 2007). This waste may contaminate our environment thereby affecting human health. On the other hand, data derived from the chemical composition could be used to qualify it for food or animal feed as avocado waste can be added to the diet of finishing pigs to boost their meal quality and health. Its medicinal values cannot be over emphasized as the fruits, leaves and seeds are used for medicine. As a result of the importance of this plant in traditional medicine, there is need to ascertain the plant chemicals that may be responsible for these health benefits (Tango et al, 2004). The present study investigated the proximate, ultimate and mineral composition of $P$. americana seed and pulp.

\section{MATERIALS AND METHODS}

\section{Collection of sample and preparation}

Samples of Persea americana used for this analysis were obtained from Uchi Market in Auchi, Estako West Local Government Area of Edo State, Nigeria. The fruits were thoroughly screened to remove the bad ones. The plant materials (pulp and seed) were identified and authenticated by Mr. Oguntokun O. Michael of the Nutrition Laboratory, Department of Animal Production and Health. Federal University of Technology, Akure, Nigeria. The identified pulp and seed were cleaned, peel removed and de-stoned. They were subjected to conditioning. In conditioning these seeds, they were sorted in group of two and three depending on availability due to the fact that some are already almost out of season. Each group was labeled accordingly. The fruits at the ripening stage were cut open to obtain their pulp and seeds. The pulp and seed were sliced and oven dried for 24 hours at $50^{\circ} \mathrm{C}$. After oven drying, the samples were then grounded to fine powder using Thomas-Wiley milling machine. The grounded samples were stored in air tight bottles till when needed for analysis (Figure 1).

\section{Analysis of $P$. americana pulp and seed}

In analyzing $P$. americana pulp and seed, two basic methods were involved; ultimate analysis and proximate analysis. The ultimate analysis covers solid, gaseous and all component elements of the product while proximate analysis covers the fixed carbon, volatile matter and moisture content and ash percentages. Both the ultimate and proximate analysis were carried out at the Department of Animal Production and Health Laboratory, Federal University of Technology, Akure, Nigeria.

\section{Determination of proximate analysis of $\boldsymbol{P}$. americana pulp and seed}

Determination of moisture, volatile matter, ash and fixed carbon in $P$. americana pulp and seed comprises of its proximate analysis.

Determination of ash content: It is the weight of residue obtained after burning a weighed quantity of avocado in an open crucible at $750^{\circ} \mathrm{C}$ in a muffle furnace till a constant weight is achieved.

$\%$ Ash in avocado $=\frac{\text { weight of residue ash formed } \times 100}{\text { Weight of avocado initially taken }}$

Determination of moisture content: The air-oven method was used to determine the moisture content of the samples. The Petri-dishes were first washed, dried in the oven, allowed to cool in a desiccator and the weight noted. $12 \mathrm{~g}$ of each of the sample was measured, transferred into the petri-dishes and weighed. The petri-dishes containing the samples were then dried in an oven at $105^{\circ} \mathrm{C}$ for 3 hours. The petri-dishes were removed from the oven, allowed to cool in the desiccator and the weight was noted (A.O.A.C 2000). This process was continued until a constant weight was obtained (A.O.A.C. 2000). The loss in weight during drying in percentage was taken to be the percentage moisture content.

$\%$ moisture $=\frac{\text { loss in weight due to drying }}{\text { Weight of sample taken }} \times 100$

$\%$ moisture $=\frac{\mathrm{W} 3-\mathrm{WA}}{\mathrm{W} 2} \times 100$

Where W3 = Initial weight of the sample, WA = constant weight after drying and $\mathrm{W} 2$ = weight of sample taken.

Determination of volatile matter: This is the loss in weight of moisture free powdered $P$ Americana pulp and seed when heated in a crucible fitted with cover in a muffle furnace at $950^{\circ} \mathrm{C}$ for $7 \mathrm{~min}$.

Volatile matters are the methane, hydrocarbons, hydrogen and carbon monoxide, and incombustible gases like carbon dioxide and nitrogen found in date. Thus, the volatile matter is an index of the gaseous fuels present. Typical range of volatile matter is 20 to $35 \%$.

$\%$ volatile mater $=$

loss in weight of moisture avocado pulp and seed

Weight of moisture avocado pulp and seed $\times 100$ 


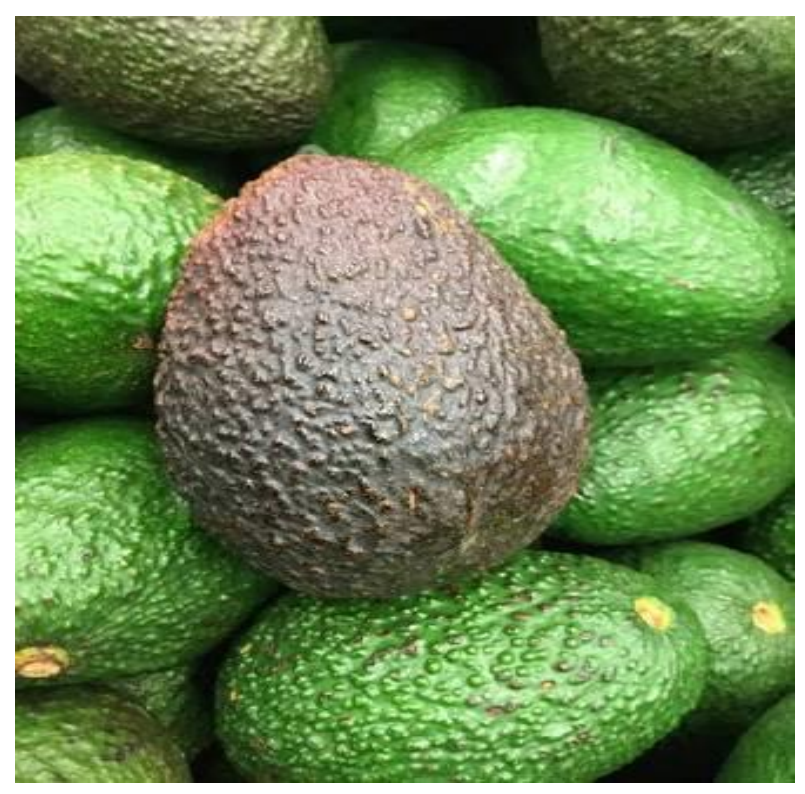

Figure 1. Ripe Hass avocado pear.

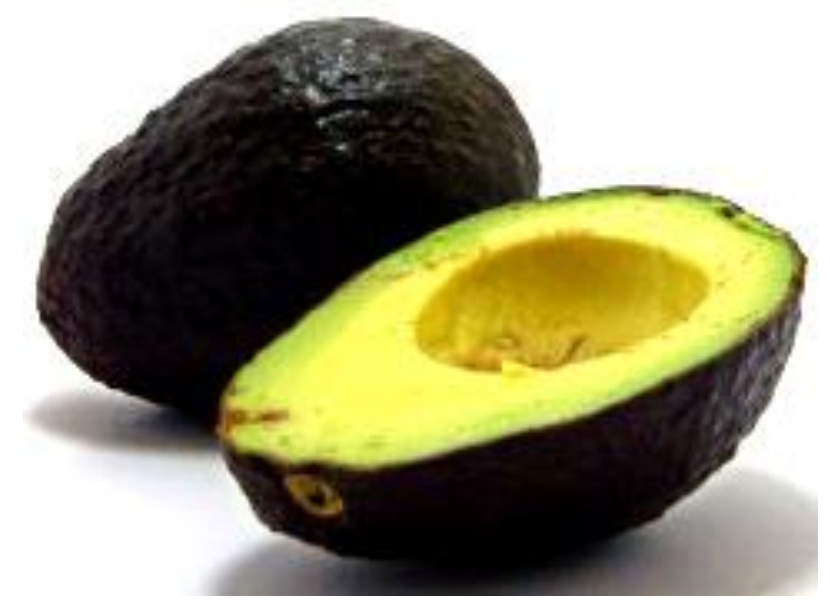

Figure 2. Cross section of Hass Avocado pulp.

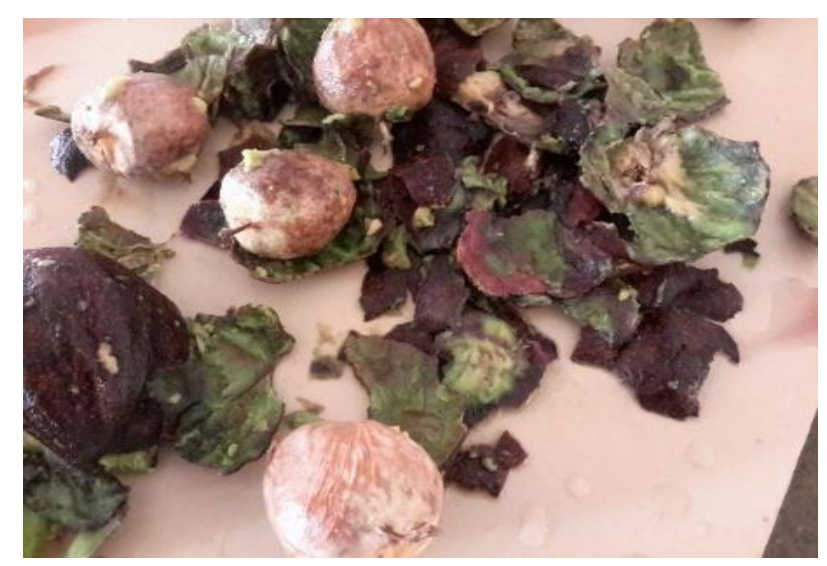

Figure 3. After de-skinning.

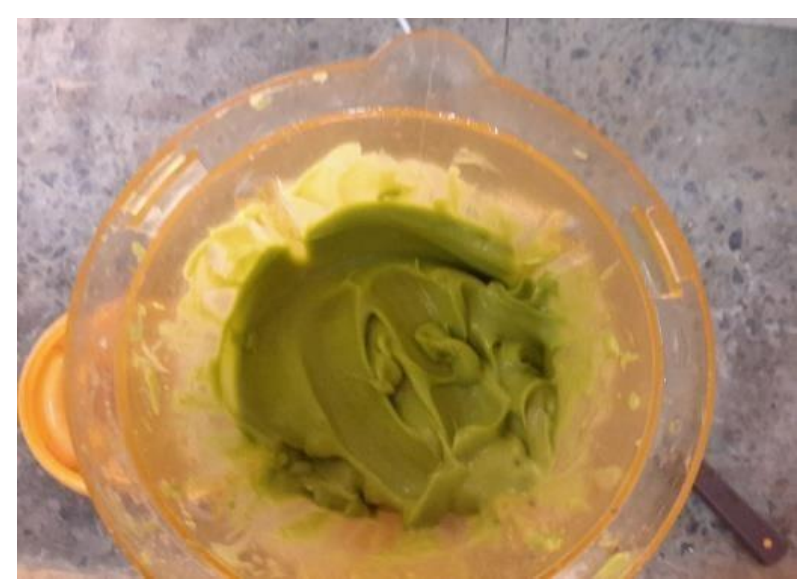

Figure 4. De-stoning and Avocado pulp after blending

Determination of fixed carbon: It is determined indirectly by deducting the sum total of moisture, volatile matter and ash percentage from 100 .

$\%$ Fixed carbon of avocado pulp and seed $=100-$ (\%moisture $+\%$ volatile matter $+\%$ ash $)$.

One gram of finely ground sample was weighed into clean, dried pre weighed crucibles with lid $\left(\mathrm{W}_{1}\right)$. The organic matter was burned off using flame (lid remove) until the sample became charred. The crucibles were then transferred to the muffle furnace set at $550^{\circ} \mathrm{C}$ (lid removed). Ashing was continued until a light grey or white ash was obtained. The crucibles were then cooled in a desiccator and weighed $\left(W_{2}\right)$ (AOAC, 1990)

\section{Determination of ultimate analysis of $P$. americana pulp and seed}

The ultimate analysis indicates the various elemental chemical constituents such as Carbon, Hydrogen, Oxygen, Sulphur and Nitrogen. It is useful in determining the quantity of air required for combustion and the volume and composition of the combustion gases. This information is required for the calculation of flame temperature and the flue duct design.

Determination of Carbon and Hydrogen: This was estimated using the Liebig's method for the estimation of carbon and hydrogen. $5 \mathrm{~g}$ of avocado pulp and seed is heated in a current of dry oxygen thereby converting $\mathrm{C}$ and $\mathrm{H}$ of avocado pulp and seed into $\mathrm{CO}_{2}\left(\mathrm{C}_{+} \mathrm{O}_{2}=\mathrm{CO}_{2}\right)$ and $\mathrm{H}_{2} \mathrm{O} \quad\left(\mathrm{H}_{2}+1_{2} \mathrm{O}_{2}=\mathrm{H}_{2} \mathrm{O}\right)$ respectively. The products of combustion $\left(\mathrm{CO}_{2}\right.$ and $\left.\mathrm{H}_{2} \mathrm{O}\right)$ are passed over weighed tubes of anhydrous calcium chloride and potassium hydroxide which absorb $\mathrm{H}_{2} \mathrm{O}$ and $\mathrm{CO}_{2}$ respectively. The increase in the weight of $\mathrm{CaCl}_{2}$ tube represents the weight of water $\left(\mathrm{H}_{2} \mathrm{O}\right)$ formed while increase in the weight of $\mathrm{KOH}$ 
tube represents the weight of $\mathrm{CO}_{2}$ formed. Percent of $\mathrm{H}$ and $\mathrm{C}$ in avocado pulp and seed were calculated as follows:

Amount of carbon in the avocado pulp and seed sample

$$
=\frac{12 \times \mathrm{z}}{44}
$$

Since, $44 \mathrm{~g}$ of $\mathrm{CO}_{2}$ is produced from $12 \mathrm{~g}$ of carbon and 32 $\mathrm{g}$ of oxygen

$\mathrm{C}+\mathrm{O}_{2}=\mathrm{CO}_{2}$

$12 \quad 32 \quad 44$

$\%$ carbon in avocado pulp and seed $=\frac{12 \times \mathrm{z}}{44 \times x}$

Similarly, amount of hydrogen in avocado pulp and seed sample $=\frac{12 \times \mathrm{y}}{18}$

Since $18 \mathrm{~g}$ of water is formed by $2 \mathrm{~g}$ of hydrogen and $16 \mathrm{~g}$ oxygen

$$
\begin{array}{ll}
\mathrm{H}_{2}+{ }_{2} & \mathrm{O}_{2}= \\
2 & \mathrm{H}_{2} \mathrm{O}
\end{array}
$$

$\%$ carbon in avocado pulp and seed $=\frac{12 \mathrm{xy}}{18 \mathrm{x} x} \times 100$

Where: $x=$ weight of avocado pulp and seed sample taken, $y=$ increase in the weight of $\mathrm{CaCl}_{2}$ tube and $z=$ increase in the weight of $\mathrm{KOH}$ tube

Determination of Sulphur: $10 \mathrm{~g}$ of avocado pulp and seed was heated with Eschka mixture (which consists of 2 parts of $\mathrm{MgO}$ and 1 part of anhydrous $\mathrm{NaCO}_{3}$ ) at $800^{\circ} \mathrm{C}$. The sulphate formed was precipitated as $\mathrm{BaSO}_{4}$ (by treating with $\mathrm{BaCl}_{2}$ ) and the Sulphur in avocado was computed as follows:

32 grams Sulphur in the avocado pulp and seed will give 233 grams $\mathrm{B}_{a} \mathrm{SO}_{4}$

Amount of sulphur in avocado pulp and seed $=\frac{32 \mathrm{y}}{233}$

$$
=0.1374 \mathrm{y}
$$

$\%$ of sulphur in avocado pulp and seed $=\frac{0.1374 \mathrm{y} \times 100}{\mathrm{X}}$

Where: $\mathrm{x}$ = weight of avocado pulp and seed sample taken and $\mathrm{y}=$ weight of $\mathrm{BaSO}_{4}$ precipitate formed.

Determination of oxygen: This was deduced indirectly as follows:

Percentage (\%) of oxygen in avocado pulp and seed $=100$

$-(\%$ of $\mathrm{C}+\mathrm{H}+\mathrm{N}+\mathrm{S}+\mathrm{ash})$
Determination of Nitrogen: MicroKjeldahl method was used to determine the nitrogen content of the Avocado pulp and seed samples (AOAC, 2000). $0.205 \mathrm{~g}$ of the samples was weighed into a Kjeldahl flask and a tablet of Kjeldahl catalyst (Sedenium catalyst) was added to the sample along with $10 \mathrm{~cm}^{3}$ of concentrrated $\mathrm{H}_{2} \mathrm{SO}_{4}$. The flask was gently placed in the digester housed in a fume cupboard. The heating was continued until a clear solution was obtained. The clear solution was cooled, poured into a $100 \mathrm{~cm}^{3}$ volumetric flask and made up to the mark with distilled water. $10 \mathrm{~cm}^{3}$ of the resulting mixture was measured into the distillation unit and $5 \mathrm{~cm}^{3}$ of $2 \%$ boric acid was pipetted into a $100 \mathrm{~cm}^{3}$ conical flask with two drops of mixed indicator and placed at the receiving end of the distillater. $40 \% \mathrm{NaOH}$ was added to the sample until alkaline condition was attained. The liberated ammonia was trapped in the boric acid solution and about $50 \mathrm{~cm}^{3}$ of the solution was collected into the conical flask. The solution in the flask was titrated with $0.01 \mathrm{MHCl}$ until the first permanent colour change was observed and result calculated.

Determination of mineral composition: The minerals were determined by dry ashing method. The samples were heated in muffle furnace at $550^{\circ} \mathrm{C}$. The produced ash was dissolved in $10 \%$ hydrochloric acid solution to determine mineral content of the sample using flame photometer for sodium and potassium and atomic absorption spectrophotometer (Buck 210 model 200). While phosphorus was determined calorimetrically by Spectronic 20 (Gallenkamp, UK) using the phosphovanado molybdate method (AOAC, 2000). Other Element such as Al, Ca, Cu, $\mathrm{Fe}, \mathrm{Mg}, \mathrm{Si}$, and $\mathrm{Zn}$ were analyzed with a Perkin-Elmer 2001 Model Inductively Coupled Plasma-Optic Emission Spectrometry (ICP-OES).

\section{RESULTS AND DISCUSSION}

In the investigated samples, the pulp of $P$. americana yielded the highest fat of $31.64 \pm 1.41$ than the seed. This implies that it is an oil fruit and the dietary fat quality can exert a protective effect on cardiovascular diseases. The consumption of foods rich in monounsaturated fatty acids (MUFA), dietary fibers, and antioxidants has been associated with lipid profile improvement and body weight loss as reported by Silva Caldas et al. (2017) The protein contents of the samples investigated ranged from $1.62 \pm 0.09$ to $19.94 \pm 1.40 \%$ in fruit which was quite higher than $15.55 \pm 0.36$ as reported by Ejiofor et al. (2018). Apart from contributing to diets, the relative impact of proteins in body system should not be neglected, this is because they replace and repair worn out tissues, form the body's structural materials, blood proteins, improve immune system (Olusanya, 2008). The seed has a Fibre content of $4.10 \pm 016$ which is higher than $3.10 \pm 0.18$ and $2.87 \pm 0.00$ reported by Arukwe et al. (2012) and Egbuonu et al. (2018) respectively. Thus, can protects the intestine from packing 
Table1. Proximate composition (\%) of the samples.

\begin{tabular}{lcc}
\hline Constituents & Seed & Pulp \\
\hline Ash & $0.84 \pm 0.02$ & $1.02 \pm 0.01$ \\
Moisture content & $13.27 \pm 0.01$ & $51.69 \pm 0.01$ \\
Carbohydrate & $48.21 \pm 4.12$ & $53.74 \pm 3.41$ \\
Fibre & $4.10 \pm 0.16$ & $1.08 \pm 0.43$ \\
Fat & $15.73 \pm 1.19$ & $31.64 \pm 1.41$ \\
Protein & $19.94 \pm 1.40$ & $1.62 \pm 0.09$ \\
\hline
\end{tabular}

Values are in means \pm standard deviations of triplicate determinations. ND= Not Detected.

Table 2. Ultimate analysis \% of the samples.

\begin{tabular}{lcc}
\hline Constituents & Seed & Pulp \\
\hline Total carbon & $85.90 \pm 0.014$ & $17.29 \pm 0.03$ \\
Hydrogen & $0.55 \pm 0.07$ & $0.65 \pm 0.07$ \\
Nitrogen & $3.17 \pm 0.01$ & $4.13 \pm 0.01$ \\
Oxygen & $9.49 \pm 0.07$ & $76.88 \pm 0.09$ \\
Sulphur & $0.07 \pm 0.01$ & $0.04 \pm 0.01$ \\
Volatile matter & $27.55 \pm 0.01$ & $0.22 \pm 0.01$ \\
Fixed Carbon & $58.35 \pm 0.04$ & $17.07 \pm 0.04$ \\
Ash & $0.92 \pm 0.03$ & $1.07 \pm 0.02$ \\
\hline
\end{tabular}

Values are in means \pm standard deviations of triplicate determinations. ND= Not Detected.

Table 3. Mineral composition of the P. americana seed and pulp samples (\%).

\begin{tabular}{lcc}
\hline Constituents & Seed & Pulp \\
\hline Sodium & $40.04 \pm 14.09$ & $51.47 \pm 0.02$ \\
Potassium & $57.35 \pm 11.53$ & $28.02 \pm 0.01$ \\
Calcium & $36.78 \pm 0.03$ & $27.13 \pm 0.02$ \\
Magnesium & $20.81 \pm 18.09$ & $40.77 \pm 0.01$ \\
Iron & $19.56 \pm 19.88$ & $12.01 \pm 0.01$ \\
Zinc & $6.47 \pm 1.32$ & $7.23 \pm 0.01$ \\
Phosphorus & $20.53 \pm 18.60$ & $31.63 \pm 0.04$ \\
Sulphur & $0.08 \pm 0.01$ & $0.12 \pm 0.02$ \\
Silicon & $16.86 \pm 23.84$ & $\mathrm{ND}$ \\
Aluminum & $\mathrm{ND}$ & $\mathrm{ND}$ \\
Chlorine & $\mathrm{ND}$ & $\mathrm{ND}$ \\
Copper & $1.09 \pm 0.13$ & $0.98 \pm 0.05$ \\
\hline
\end{tabular}

Values are means \pm standard deviations of triplicate determinations. ND $=$ Not Detected.

and increases faecal bulk. It also reduces the risk of colon cancer by diluting the augmented concentrations of colonic bile acid that arises due to high fat diet (Dillard 1990).

Table 2 shows the ultimate analyses of the samples. The percentage total carbon was $85.90 \pm 0.014$ and $17.29 \pm 0.03$ for the seed and the pulp respectively. These were higher than 46.0 that was reported by Sánchez et al. (2017). The result obtained showed that the seed has the higher percentage of total carbon than the pulp and every other element which implies that it can be used to generate energy (Arukwe et al., 2012). Hydrogen was $0.55 \pm 0.07$ and $0.65 \pm 0.07$ in pulp and seed respectively which may help to prevent metabolic syndrome. It can also be seen from the Table 2 that the pulp of $P$. americana contains more oxygen than the seed which can help to increase the shelf life of the fruit (Ayoola et al., 2012).

Table 3 shows the mineral composition of $P$. americana seed and pulp. The total carbon was found as $(85.89 \pm 0.03 \%)$, Hydrogen $(68.19 \pm 25.01 \%)$, Nitrogen $(2.63 \pm 1.81 \%)$, Oxygen $(6.36 \pm 4.50 \%)$ and $(76.88 \pm 0.09 \%)$ 
for the pulp and these values increasing the shelf life of the seed. Sodium $(40.04 \pm 14.09 \%)$ for seed and the higher amount of it in the pulp $(51.47 \pm 0.02 \%)$ which was quite higher than $12.61 \pm 1.19$ as reported byArukwe et al. (2012). High content of sodium in the body has been linked with hypertension (Olusanya, 2008), but this may not be possible if there is a higher content of potassium. The percentage of Potassium was higher than any other investigated minerals except the percentage of total carbon and nitrogen. Potassium is essential for balancing electrolyte and the control of high pressure. The seed and pulp also contained large proportion of potassium of $57.35 \pm 11.53$ and $28.02 \pm 0.01$ which can help to prevent kidney stones, osteoporosis, stroke and high blood pressure and also helps to strengthen the bones (Olusanya, 2008). Among the minerals, calcium was reported to be $36.78 \pm 0.03$ in the seed and $27.13 \pm 0.02$ in the pulp, which was quite higher than $14.15 \pm 3.01$ reported by Arukwe et al. (2012).

The mineral composition of $P$. americana seed was observed to have a magnesium composition of $20.81 \pm 18.09 \%$ in the seed and $40.77 \pm 0.01$ in the pulp which indicate that $P$. americana can be used to cure diabetes, hypertension, depress and osteoporosis. Iron composition of $19.56 \pm 19.88$ and $12.01 \pm 0.01$ were obtained for the seed and the pulp respectively. This indicated that the fruit can be used to synthesize red blood cells and help prevent iron-deficiency anemia (Arukwe et al, 2012).

The report also shows that the seed and the pulp contains $20.53 \pm 18.60$ and $31.63 \pm 0.04$ of Phosphorus respectively which is higher than $31.33 \pm 6.11$ reported by Arukwe et al. (2012). This helps in the formation of bones and teeth. Silicon was detected in the seed $(16.86 \pm 23.84)$ but was not detected in the pulp. These variations of the report with other results perhaps may be due to seed varieties, agricultural conditions, conditions of the climatic and methods used for determination. The pulp and seed studied contained appreciable amounts of magnesium, phosphorus, Oxygen, Sulphur, Iron, Zinc, Copper and calcium. These are very important in human health. They are required for formation of teeth and bones, blood clotting and other function of the body (Olusanya, 2008). The absence of chlorine and aluminium, could imply that the investigated samples do not contain toxic metals.

\section{Conclusion}

From the results obtained in this research, $P$. americana can be an outstanding substitute for fat in baking industry, considering its chemical components and the benefits of its compounds (Okolo 2012). In addition, taken into consideration the specie and diversity of the plant varieties, cultivation is easy and the fruit is readily availability, any time of the year. The crop can be used as raw material in the cosmetic and pharmaceutical industries, and also acts as a medicinal value in herbal preparation (Onwuka 2005). The pulp residue can also be used in manufacturing food products for man and animal consumption. Several studies have proven the health benefits of $P$. americana intake, especially in reducing saturated fat and prevention of other related heart diseases. With a lot of researches still going on about $P$. americana and its nutritional characteristics and benefits, there should be an increase in $P$. americana production and utilization in Nigeria, and in other countries.

\section{CONFLICT OF INTEREST}

The authors declare that they have no conflict of interest.

\section{REFERENCES}

Arukwe, U., Amadi, B. A., Duru, M.K.C., Agomuo, E. N., Adindu, E. A., Odika, P. C., Lele, K. C., Egejuru, L., \& Anudike, J. (2012). Chemical composition of Persea americana leaf, fruit and seed. IJRRAS. 11(2), 346-349.

Ayoola, P. B., Adeyeye, A., \& Onawumi, O. O. (2012). Chemical evaluation of food value of groundnut (Arachi hypogaea) seeds. American Journal of Food and Nutrition, 2(3), 55-57.

Dillard, C. J., \& German, Enig, M. (1990). Coconut: In support of good health in the 21st century. Pp.1-27.

Egbuonu, A. C. C., Opara, I. C., Onyeabo, C., \& Uchenna, N. O. (2018). Proximate, Functional, Antinutrient and Antimicrobial Properties of Avocado Pear (Persea americana) Seeds. J. Nutr. Health Food Eng., 8(1), 00260.

Ejiofor, N. C., Ezeagu, I. E., Ayoola, M., \& Umera, E. A. (2018). Determination of the chemical composition of avocado (Persea americana) seed. Adv. Food Technol. Nutr. Sci. Open J., SE(2), S51-S55.

Nwaokobia, K., Ogboru, R. O., \& Idibie, C. A. (2018). Extraction of edible oil from the pulp of Persea americana (Mill) using cold process method. World News of Natural Sciences, 17(2018) $130-140$

Ojewole, J., Kamadyaapa, D. R., Gondwe, M. M., Moodley, K., \& Musabayane, C. T. (2007). Cardiovascular effects of Persea americana Mill (Lauraceae)(avocado) aqueous leaf extract in experimental animals. Cardiovascular Journal of South Africa, 18(2), 69-76.

Okolo, S. C., Olutayo, O., Doyinsola, I., Adedayo, A., Ikokoh, P. P., \& Orishadipe, A. T. (2012). Comparative proximate studies on some Nigerian food supplements. Ann Biol Res.; 3(2), 773779.

Olusanya, J. O. (2008). Proteins, In: Essentials of food and nutrition. Apex Books Limited, Lagos. Pp.13-21.

Onwuka, G. I. (2005). Food analysis and instrumentation (Theory and Practice). 1st edition. Naphtali prints, Surulere, Lagos. Pp. 50-58.

Owolabi, M. A., Jaja, S. I., \& Coker, H. A. (2005). Vasorelaxant action of aqueous extract of the leaves of Persea americana on isolated thoracic rat aorta. Fitoterapia, 76(6), 567-573.

Rizvi, S., Raza, S. T., Ahmed, F., Ahmad, A., Abbas, S., \& Mahdi, F. (2014). The Role of Vitamin E in Human Health and Some Diseases. Sultan Qaboos Univiversity Medical Journal, 14(2), 157-165.

Sánchez, F., Agudín, F., \& San Mıguel, G. (2017). Granular activated carbons from avocado seeds. $15^{\text {th }}$ International Conference on Environmental Science and Technology. Rhodes, Greece, 31 August to 2 September 2017. 
Silva Caldas, A. P., Chaves, L. O., Linhares Da Silva, L., de Castro Morais, D., \& Gonçalves Alfenas, R. D. C. (2017). Mechanisms involved in the cardioprotective effect of avocado consumption: A systematic review. International Journal of Food Properties, 20(sup2), 1675-1685.

Tango, J. S., Carvalho, C. R. L., \& Soares, N. B. (2004). Physical and chemical characterization of avocado fruits aiming its potencial for oil extraction. Revista Brasileira de Fruticultura, 26(1), 17-23.

Uwakwe, A. A., \& Ayalogu, O. (1998). Biochemistry (A tropical approach). Fius Publishers, Port Harcourt, Nigeria. 1, 3-5. 